\title{
Preparation and Characterization of Chitosan-Gelatin-Glycerol Biocomposite for Primary Wound Dressing
}

\author{
Suryati*, Dwi Ayu Lestari, Sulhatun, Meriatna \\ Department of Chemical Engineering, Faculty of Engineering, Universitas Malikussaleh, Aceh, Indonesia \\ *Corresponding author E-mail: suryati@unimal.ac.id
}

Manuscript received 5 Nov 2021; revised 10 Nov 2021; accepted 1 Jan 2022. Date of publication 10 Jan 2022

\begin{abstract}
This study aimed to examine the laboratory-based preparation of chitosan-gelatin bio-composite with the addition of glycerol as an additive to improve its quality which could be further applied for primary wound dressing. The method consisted of three stages; the first was the preparation of raw materials, the second was the preparation of the bio-composites, and the last was the characterization. In this study,chitosan $90.2 \%$ DD and gelatine (dissolved in 1\% acetic acid) were blended at volume ratios v/v (30:70), and glycerol was added into blended at five different volume $20,25,30,35,40,45(\mathrm{~mL})$ respectively. The biocomposites is then shaped in a glass mold, allowed to at room temperature for 24 hours, and dried in oven at $50^{\circ} \mathrm{C}$ for 48 hours. The chitosan-gelatin-glycerol bio-composites was smooth, flexible, transparent thin sheet and non-porous. The optimum thickness $(4.01 \mathrm{~mm})$ was obtained from a bio-composite with chitosangelatin-glycerol ratio of 30:70:45. The same composition rasio was found to have the liquid absorbance reaching $140.34 \%$. The biocomposite with a chitosan-gelatin-glycerol ratio of 30:70:45 also had the highest swelling ability in saline (168.06\%). The functional group analysis using Fourier Transform Infrared (FT-IR) spectroscopy revealed the possession of hydroxyl (O-H) and carbonyl (C-O) functional groups suggesting its good biodegradability and environmentally friendly properties. Taken altogether, the results imply the wound dressing bio-composite is hydrophilic. Based on the results of characteristic testing, it is shown that the chitosan-gelatin-glycerol biocomposite has the potential to be applied as a primary wound dressing, which is ideal for wound healing and protection.
\end{abstract}

\section{Keywords: Biocomposite, Gelatin, Glycerol, Chitosan, Primary Wound Dressing.}

\section{Introduction}

Skin is the largest organ of the body that is composed of different types of connective tissue, nerves, muscles and epidermis. It has many functions and is responsible for providing sensation, thermoregulation, biochemistry, immunity, protection and maintaining fluid balance. Injuries could be defined as a damage or disorder in anatomical structures and organ functions (such as those occur on skin, subcutaneous tissue, muscles, tendons, nerves, blood vessels, and even bones) [1] [2]. Open wounds cause a susceptibility against infections, especially bacterial infections, by becoming an entry point for systemic infections. Infected wounds have slower recovery and often lead to the formation of exudates and toxins as the result of cell death. Hence, it is important to stimulate healing and restoring the normal function of the injured body parts to prevent the onset of infection and to relieve the discomfort and pain [3].

Wound healing could carried out by covering the injured part of the skin with a wound dressing. A pad that has the ability to stimulate the healing process could be used for wound dressing. A wound dressing pad should be able to create a humid atmosphere, control excess exudate, and maintain the condition of the body to be stable, and cannot be passed through by microorganisms [4]. Chitosan is a natural ingerdient possessing an anti-microbial properties which could be used for wound dressing. Commonly, chitosan is made from waste of shrimp, crab, and so on causing its abundant availability [5]-[7]. Chitosan is obtained by N-deacetilation from chitin and consists of glucosamine and $\mathrm{N}$-acetylglukosamine. Chitosan has been widely developed studied for a variety of applications due to biocompatibility, biodegradability, mucoadhesive, and derivatives of abundant and inexpensive biomass. Chitosan also has antimicrobial activity, wound healing properties and hemostatic activity which makes chitosan-based composites particularly useful in the biomedical field [8]._For wound healing purpose, chitosan has been prepared with glycerin addition and loaded with anti-bacterial drugs (tetracycline hydrochloride and silver sulfadiazine) through solvent evaporation methods [9]. The foregoing study reported a promising potential of chitosan-based bio-composite for the treatment of bacterial infections during wound healing [10] [11].

Gelatin is a natural polymer that has been approved by the FDA (Food and Drug Administration) for its distribution. Gelatin is collagen that is partially hydrolyzed and has biodegradable, non-toxic, biocompatible properties, cheap and easy to obtain, leading to its wide spectrum of usages, especially in the food and medical industries [12] [13]. As a wound dressing material, gelatin contains peptides contributing to introduce integrin receptors in cells, which are essential for cell adhesion. In addition, gelatin tends to form nanofiber 
structures that are essential for skin regeneration [14]. Gelatin is a natural ingredient that contains high amino acids and is able to form a unique binding action, so that it is able to form hydrogels. Gelatin hydrogels have gained a lot of interest in tissue engineering due to their non-immunogenic properties [15] [16] [17].

Glycerol is a hydrogenated alcohol, with another name being glycerin or 1,2,3-propanetriol. The physical properties of glycerol are colorless, odorless, sweet taste, and liquid. It has melting point of $17.8^{\circ} \mathrm{C}$ and boiling point of $290^{\circ} \mathrm{C}$, which can be dissolved in water or ethanol. Glycerol is hygroscopic (absorbing water from the air), allowing it to use as moisturizer in cosmetics. Glycerol is present in the form of esters (glycerides) in all animals and vegetable fats and oils. Glycerol is a type of plasticizer that is hydrophilic, which could add polar properties and higher solubility in water [18]. Herein, gelatin was combined with chitosan and glycerol to obtain a bio-composite with excellent characteristics, which could be applied for primary wound dressings [19].

\section{Literature Review}

\subsection{Chitosan}

Chitosan is a polymer of 2-acetamido-2-deoxy-D-glucose. To distinguish the polymer chitin and chitosan based on nitrogen content. Chitin polymer have nitrogen content less than $7 \%$ and chitosan have nitrogen content more than $7 \%$. In the chitin and chitosan are compunds that are not limited by exact stoichiometry. The use of chitosan is very widely used as a food preservative (the replacement of formalin and borax), waste treatment, slimming medicine, cosmetic, ect. Chitosan is an active group that will be associated with microbes so that chitosan is also able to slow down the addition of microbes [20].

\subsection{Gelatin}

Gelatin is a protein obtained by partial hydrolysis of collagen from the skin, white connective tissue and bones of animals. Gelatin absorbs 5-10 times its weight in water. Gelatin dissolves in hot water and when cooled will form a gel. Gelatin has distinctive properties, namely changing reversibly from a sol (colloid) form to a gel form, swells in cold water, can form a film and affect the viscosity of a material. The use of gelatin is very broad, especially in the food and non-food industries. Gelatin also has many functions and is very applicable to its use in the food and non-food industries. The use of gelatin in the food industry for example, jelly products, in the meat and dairy industry and in low fat food supplement products. In the non-food industry, gelatin is used for example in the photo film industry [21].

\subsection{Glycerol}

Glycerol is a sugar alcohol so it has a sweet taste that contains three hydroxyl groups and has one - $\mathrm{OH}$ group, which causes glycerol to dissolve in water. Glycerol is an important part of triglycerides (fats and oils). Coconut oil contains glycerol about $13.5 \%$ while in other oils it contains glycerol around $9 \%-12 \%$. Glycerol is a colorless and odorless viscous liquid. In addition, glycerol is a by-product of biodiesel production through the transesterification reaction of vegetable oils [22].

\subsection{Wound Dressing}

Wound dressings are commonly used to speed up various stages of wound healing and can create better conditions for healing. The wound dressing selected must have criteria including being able to regulate wound moisture, assist wound healing (not damage skin tissue), help air circulation from wound tissue and the surrounding environment, easy to apply and remove after use and must be sterile, non-toxic and non-toxic. allergy [23].

\section{Method}

Apparatus used in this research were oven, magnetic stirrer, hot plate, glass mold, measuring glass, spatula, analytical balance sheet, funnel, Beaker glass, Erlenmeyer, screw micrometer, and a set of spectrophotometer tools. The materials used were chitosan, gelatin, glycerol, distilled water, acetic acid 1\%, potassium bromide, sodium chloride, and phosphate buffered saline. This research consisted of three stages, namely the preparation of raw materials, the bio-composite fabrication, and the characterization (Figure 1).

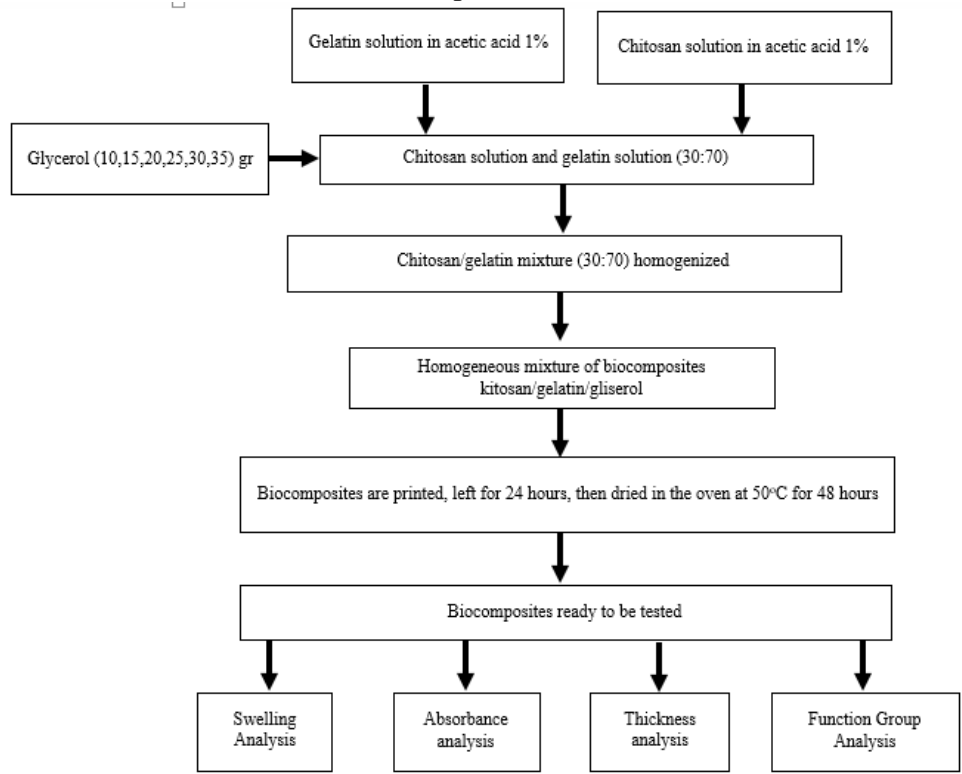

Fig 1. Flow-chart depicting the preparation of chitosan-gelatin-glycerol biocomposite 
Firstly, chitosan ( $2 \mathrm{~g}$ ) and gelatin $(2 \mathrm{~g})$ were dissolved in $100 \mathrm{~mL}$ acetic acid $1 \%$ using a magnetic stirrer until homogenous. Secondly, a solution of chitosan and gelatin were mixed with a composition of 30:70 (v/v), followed by an addition of glycerol ranged from 20 to 45 g. Afterward, the mixture was homogenized using magnetic stirrer. The casting solution was then poured onto a glass mold $\left(7 \mathrm{x} 7 \mathrm{~cm}^{2}\right)$ so that the thickness obtained was $7 \mathrm{~mm}$. Thereafter, the solution was left at room temperature for 24 hours to obtain a solid biocomposite. It was then ovendried for 48 hours at $55^{\circ} \mathrm{C}$.

In the third stage, the prepared bio-composites were characterized for their thickness, liquid absorbance, swelling, and functional groups. The thickness was carried out using screw micrometers and followed by a calculation using Equation 1 .

Thickness $=\mathrm{Su}+(\mathrm{Sn} \times 0,01)$

Where,

$\mathrm{Su}=$ Main scale $(\mathrm{mm})$

$\mathrm{Sn}=$ Nonius scale $(\mathrm{mm})$

The absorbance was calculated with Equation 2.

$\%$ Absorbance $=\frac{w s-w d}{w s} \times 100 \%$

Where,

$\mathrm{W}_{\mathrm{s}}=$ membrane weight after being immersed in a PBS solution

$\mathrm{W}_{\mathrm{d}}=$ membrane weight before being immersed in a PBS solution

As for the swelling, it was calculated using Equation 3.

$\%$ Swelling $=\frac{w s-w d}{w s} \times 100 \%$

Where :

$\mathrm{W}_{\mathrm{s}}=$ Membrane weight after being immersed in $\mathrm{NaCl}$

$\mathrm{W}_{\mathrm{d}}=$ Membrane weight before being immersed in $\mathrm{NaCl}$

To identify the functional group, sample was made in a shape of a thin film with a size of $1 \mathrm{x} 1 \mathrm{~cm}^{2}$. The sample was inserted into the tube of the Fourier Transform Infrared (FT-IR) device with observation wavenumber ranged from 4000 to $500 \mathrm{~cm}^{-1}$.

\section{Results and Discussions}

Thickness tests were performed to determine the effect of glycerol addition on the mixture of chitosan and gelatin. It was carried out using a screw micrometer with an accuracy scale reaching $0.01 \mathrm{~mm}$. For this purpose, the samples were measured from 3 different sides. The effect of the composition on the material thickness could be observed in Figure 2.

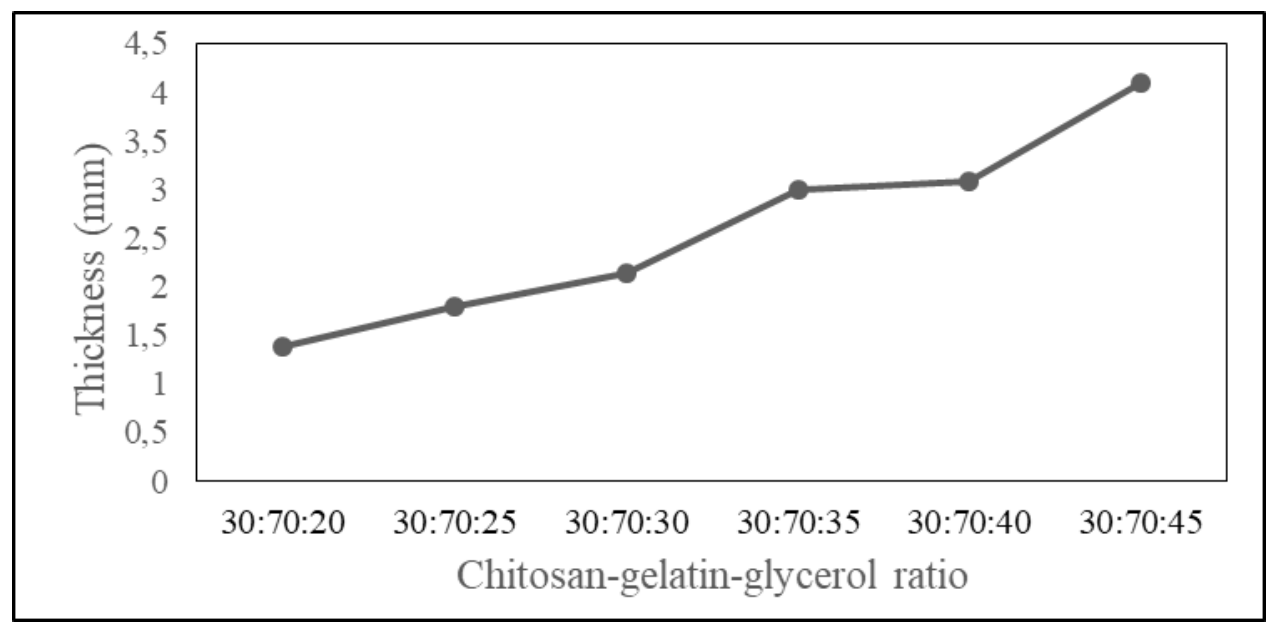

Fig 2. Effect of chitosan-gelatin-glycerol ratio against the bio-composite thickness.

It shows that the higher glycerol loading in the chitosan and gelatin mixture (30:70) resulted in thicker bio-composite. It is due to the fact that glycerol is viscous liquid which is easy to bind with water and consequently increase the viscosity of the solution [24]. If the mixture of wound dressings is getting thicker, then the composition is more solid / denser so that the thickness will increase. Based on Figure 2, the highest thickness was $4.01 \mathrm{~mm}$ obtained from a bio-composite with chitosan-gelatin-glycerol ratio of 30:70:45.

\subsection{Liquid Absorbance}

Liquid absorbance test aimed to investigate the absorption capability of chitosan-gelatin-glycerol bio-composite. The liquid used in the absorbance test was Phosphate Buffer Saline (PBS) solution with a pH of 7.3 for 12 hours. The bio-composite was weighed before and after the immersion into a PBS solution, which was prepared by dissolving PBS tablet in $100 \mathrm{~mL}$ distilled water. The effect of the composition on on the \% absorbance has been presented in Figure 3. 


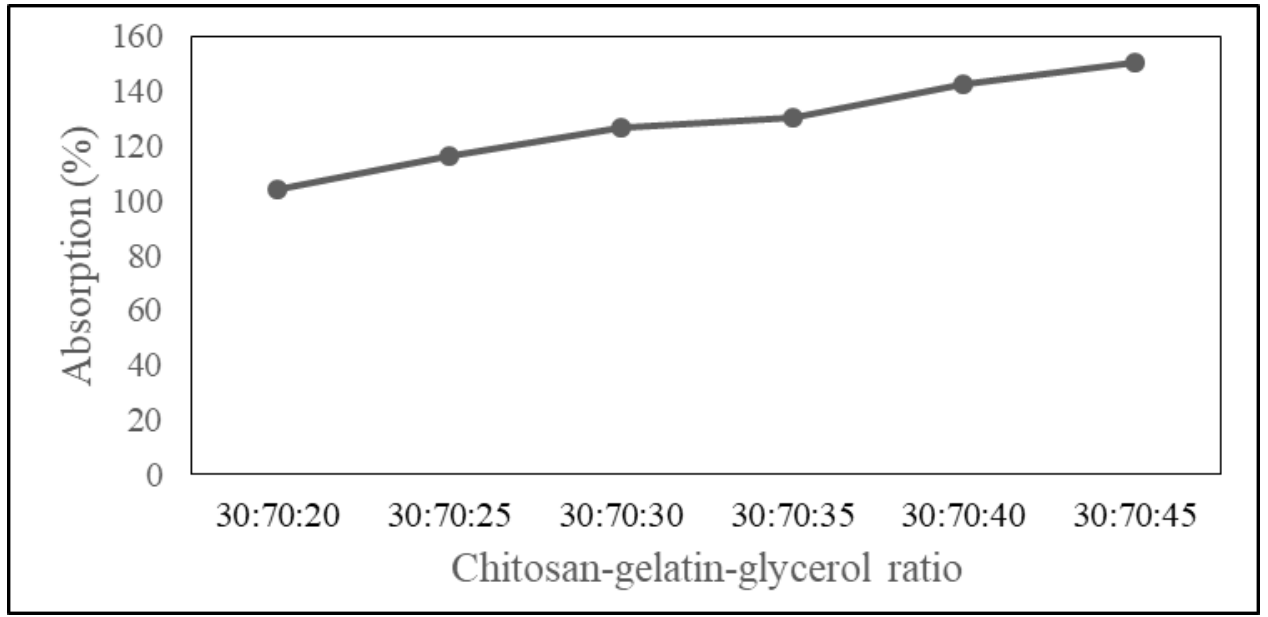

Fig 3. Effect of chitosan-gelatine-glycerol ratio against the absorbance of the bio-composite

It shows that the \% absorbance increased alowng with an increase on glycerol addition. It is stem from the fact that gelatin has hydrophilic properties that could absorb water up to 5 times than its original weight [25]. Gelatin is a hydrochloroid that is hydrogel, possessing enough water permeability to control the release and absorption of exudate during the wound treatment. In addition, the more glycerol increases, the bubbles on the surface of the bio-composite were found less, allowing enlarged bubly cavity. This finding also suggests the prepared biocomposite potential in wound dressing which could provide moist conditions around the wound and capable of absorbing fluids from the wound. Based on Figure 3, the highest absorbance (150.34\%) was obtained from the bio-composite with chitosan-gelatin-glycerol ratio of 30:70:45.

\subsection{Swelling Profile}

Analysis of $\%$ swelling was conducted to investigate the amount of fluid absorbed leading to the expanded size of the material. The value was obtained by calculating the dry weight of the biocomposite prior to the immersion into $\mathrm{NaCl}$ liquid and its wet weight after 4-hours immersion. The effect of the glycerol addition to the \% swelling of the material could be observed in Figure 4.

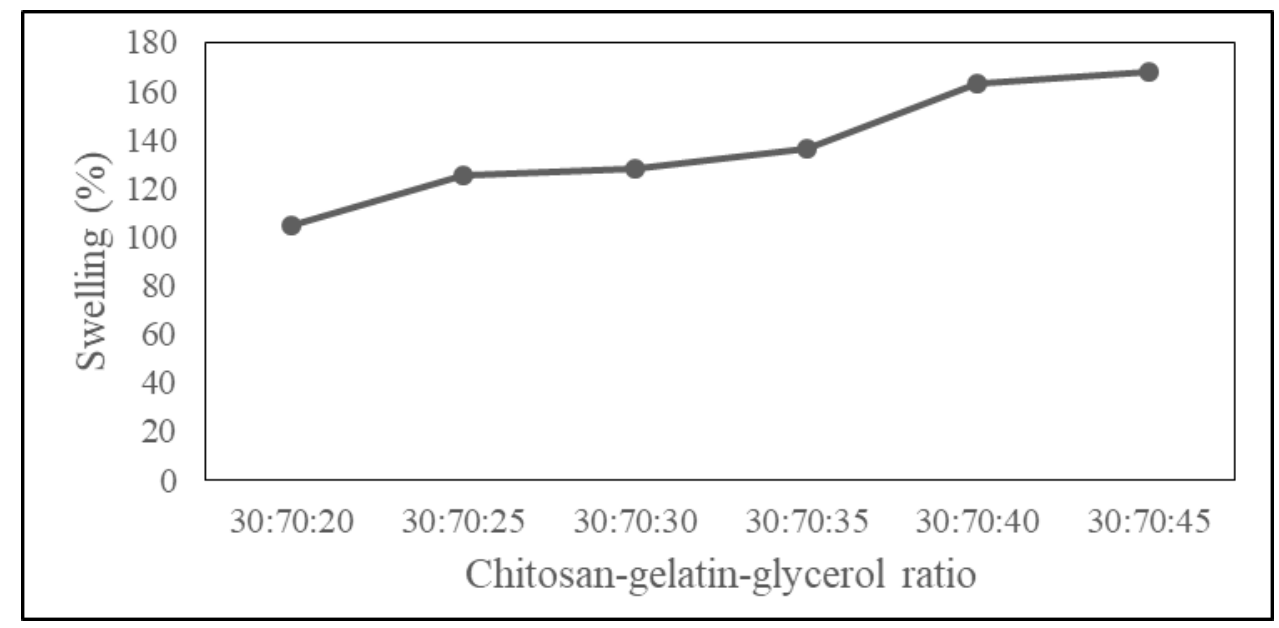

Fig 4. Effect of chitosan-gelatin-glycerol ratio against the swelling percentage of the biocomposite

The results revealed glycerol addition increased the \% swelling of the bio-composite in concentration manner. It is ascribed to the reduction of chitosan's hydrophobicity and water insolubility upon glycerol addition. Furthermore, higher glycerol loading resulted in less bubles on the bio-composite surface along with enlarged buble cavity. Hydrophilicity of the glycerol is also responsible for this phenomenon. Reduced number of bubbles and increased bubble cavities cause the surface of the film to get smoother [26]. Based on Figure 4, bio-composite with chitosan-gelatin-glycerol ratio of 30:70:45 yielded the highest swelling percentage of $168.06 \%$.

\subsection{Functional Groups}

Functional group analysis carried out in FT-IR spectrometer aimed to identify the consisting compounds, especially organic compounds both qualitatively and quantitatively. The analysis was done by preparing the sample into a thin and clear film sized $1 \times 1 \mathrm{~cm}^{2}$. Thereafter, the sample was inserted into the tube of the FT-IR device to allow the functional group reading at 4000 to $500 \mathrm{~cm}^{-1}$ wavenumber [27]. The spectral analysis was done by observing the shape of the absorbance bands, where specific peaks could be assigned to certain funcitonal group in a compound. FT-IR spectra of the bio-composite samples have been presented in Figure 5. 


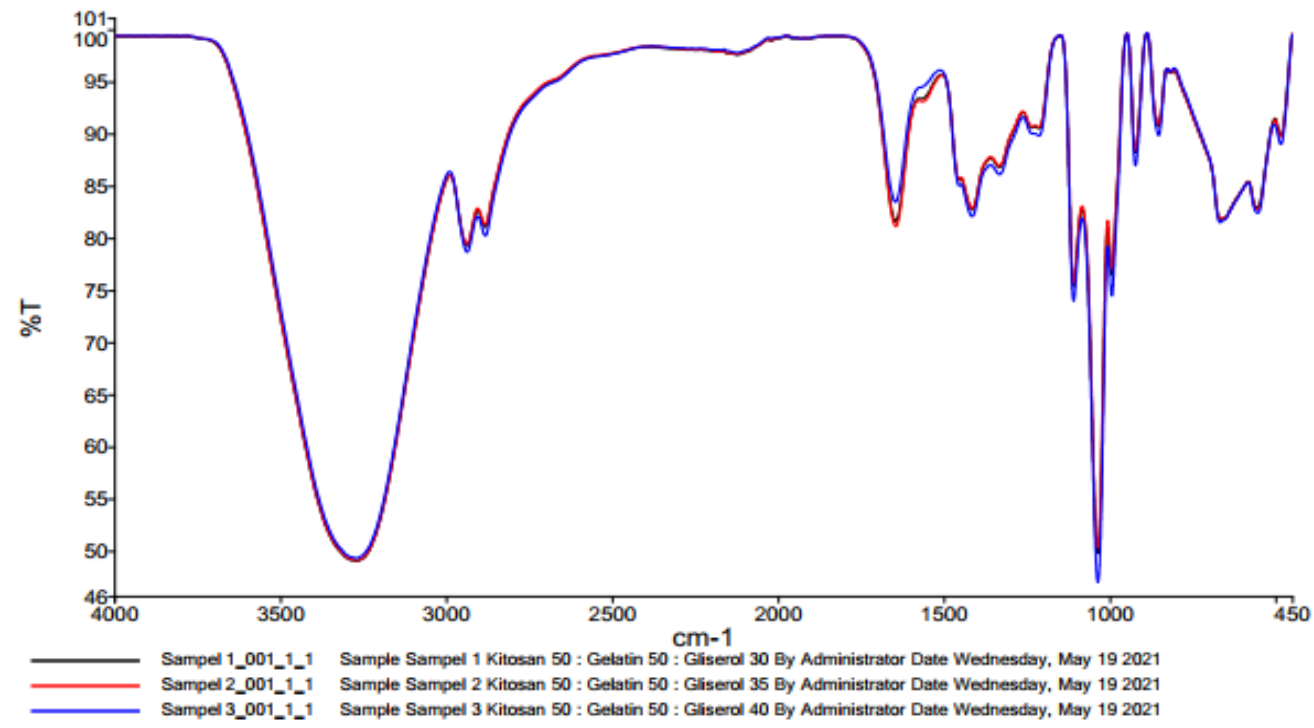

Fig 5. FT-IR spectra of the prepared bio-composites

The results revealed the presence of $\mathrm{O}-\mathrm{H}$ group at $3287 \mathrm{~cm}^{-1}, \mathrm{C}-\mathrm{H}$ (alkane) at $2940 \mathrm{~cm}^{-1}$ and $1417 \mathrm{~cm}^{-1}, \mathrm{C}=\mathrm{C}$ (alkene) at $1646 \mathrm{~cm}^{-1}, \mathrm{C}-\mathrm{N}$ (amine) at $1109 \mathrm{~cm}^{-1}, \mathrm{C}-\mathrm{O}$ at $1036 \mathrm{~cm}^{-1}$, and $\mathrm{C}-\mathrm{H}$ functional groups at a range from 659 to $993 \mathrm{~cm}^{-1}$. The identification of the prepared bio-composite with different glycerol content indicates the absence of new functional group. The presence of $\mathrm{O}-\mathrm{H}$ and the $\mathrm{C}-\mathrm{O}$ functional groups further suggests the hydrophilicity tendency of the bio-composite along with its biodegradable and eco-friendly properties.

\section{Conclusions}

Highest Values Of Thickness (4.01 Mm), Liquid Absorbance (150.34\%), And Swelling Degree (168.06\%) Were Obtained From Chitosan-Gelatin-Glycerol Bio-Composite With A Ratio Of 30:70:45. Hydroxyl And Carbonyl Functional Groups Were Identified Within The Bio-Composite Suggesting Its High Biodegradability And Eco-Friendly Properties. Collectively, The Bio-Composite Could Be Concluded To Possess High Hydrophilicity

\section{Acknowledgement}

The Authors Appreciate The Funding From The Non-Tax State Revenue Fund (Pnbp) In The List Of Budget Implementation (DIPA) Of Malikussaleh University In 2021. The Authors Also Appreciate The Institute Of Research And Community Service (LPPM) Of Universitas Malikussaleh For Their Assistance During The Research And Writing Of This Article

\section{References}

[1] Gito and E. Rochmawati, "Efektifitas Kandungan Modern Wound Dressing Terhadap Perkembangan Bakteri Staphylococcus Aureus," J. Keperawatan, vol. 9, no. 2, p. 88, 2018.

[2] S. Jalalul Akbar, M. Maizuar, K. Yusuf, and J. Arfiandi, "Monitoring the Dynamic Behavior of PCI Bridges Using Short Period Seismograph and CSI Bridge Modeling," Int. J. Eng. Sci. Inf. Technol., vol. 1, no. 4, 2021, doi: 10.52088/ijesty.v1i4.168.

[3] E. Kurniawaty, N. R. Putranta, F. Kedokteran, and U. Lampung, "Potensi Biopolimer Kitosan Dalam Pengobatan Luka Potency of Chitosan Biopolymer for Wound Treatment," Medula, vol. 9, no. 10, pp. 459-464, 2019.

[4] D. L. Pasaribu et al., "Jurnal Teknologi Kimia Unimal PEMBUATAN BIOKOMPOSIT KITOSAN / ALGINAT / KOLAGEN UNTUK APLIKASI," vol. 1, no. Mei, pp. 48-60, 2021.

[5] W. Damayanti et al., "Masyarakat Pengolahan Hasil Perikanan Indonesia APLIKASI KITOSAN SEBAGAI ANTIBAKTERI PADA FILET PATIN SELAMA PENYIMPANAN SUHU RENDAH Application of Chitosan as Antibacterial for Pangasius Fillet at Low Temperature Storage," vol. 19, pp. 321-328, 2016, doi: 10.17844/jphpi.2016.19.3.321.

[6] R. Rahmi, S. Lubis, N. Az-Zahra, K. Puspita, and M. Iqhrammullah, "Synergetic photocatalytic and adsorptive removals of metanil yellow using $\mathrm{TiO} 2 /$ grass-derived cellulose/chitosan $(\mathrm{TiO} 2 / \mathrm{GC} / \mathrm{CH})$ film composite," Int. J. Eng., vol. 34, no. 8, pp. 1827-1836, 2021, doi: 10.5829/ije.2021.34.08b.03.

[7] H. Fathana, M. Iqhramullah, R. Rahmi, A. Adlim, and S. Lubis, "TOFU WASTEWATER-DERIVED AMINO ACIDS IDENTIFICATION USING LC-MS/MS AND THEIR USES IN THE MODIFICATION OF CHITOSAN/TiO2 FILM COMPOSITE," Chem. Data Collect., p. 100754, 2021, doi: https://doi.org/10.1016/j.cdc.2021.100754.

[8] H. P. S. Abdul Khalil et al., "A review on chitosan-cellulose blends and nanocellulose reinforced chitosan biocomposites: Properties and their applications," Carbohydr. Polym., vol. 150, pp. 216-226, 2016, doi: 10.1016/j.carbpol.2016.05.028.

[9] K. Komposit et al., "MAYANG SARI KARAKTERISASI KOMPOSIT PENYEMBUH LUKA DARI KITOSAN-," 2021.

[10] S. Ali Rafsanjani, F. E. Rooslan Santosa, and R. Durrotun Nasihien, "Analysis of Planning for Clean Water Needs at Grand Sagara West Surabaya Hotel With the Green Buillding Concept," Int. J. Eng. Sci. Inf. Technol., vol. 1, no. 2, 2021, doi: 10.52088/ijesty.v1i2.55.

[11] S. Syafwandi, D. Setyo Sembodo, A. Tua Munthe, and A. Sumarno, "Analysis of The Use of Sawdust Waste As Concrete Mixture Add Material Against Workability and Compressive Strength Concrete With Three Concrete Treatment Methods," Int. J. Eng. Sci. 
Inf. Technol., vol. 1, no. 2, 2021, doi: 10.52088/ijesty.v1i2.109.

[12] T. Mutia et al., "Preparasi Dan Karakterisasi Membran Serat Nano Polivinil Alkohol / Gelatin Dengan Antibiotika Topikal Menggunakan Metode Electrospinning Preparation and Characterization of Polyvinyl Alcohol / Gelatin Nanofibrous Membranes With Topical Antibiotics By Elec," pp. 95-106, 2020.

[13] Z. Azmi, "Artificial Neural Network Model For Wind Mill," Int. J. Eng. Sci. Inf. Technol., vol. 1, no. 3, 2021, doi: 10.52088/ijesty.v1i3.84.

[14] Y. Zheng et al., "Gelatin-Based Hydrogels Blended with Gellan as an Injectable Wound Dressing," ACS Omega, vol. 3, no. 5, pp. 4766-4775, 2018, doi: 10.1021/acsomega.8b00308.

[15] F. M. Tarmidzi, I. K. Maharsih, T. R. Jannah, and C. S. Wahyuni, "Sintesis Hidrogel Pektin - Gelatin dengan Penambahan Ekstrak Kulit Buah Naga Sebagai Kandidat Pembalut Luka Bakar," J. Tek. Kim. dan Lingkung., vol. 4, no. 1, p. 53, 2020, doi: 10.33795/jtkl.v4i1.128.

[16] S. H. Malih, "Stability and convergence theorems of pointwise asymptotically nonexpansive random operator in banach space," Int. J. Nonlinear Anal. Appl., vol. 12, no. 1, 2021, doi: 10.22075/ijnaa.2021.4681.

[17] D. Riyan Rizaldi, A. Doyan, Z. Fatimah, M. Zaenudin, and M. Zaini, "Strategies to Improve Teacher Ability in Using The Madrasah E-Learning Application During the COVID-19 Pandemic," Int. J. Eng. Sci. Inf. Technol., vol. 1, no. 2, 2021, doi: 10.52088/ijesty.v1i2.47.

[18] Lismawati, "Pengaruh Penambahan Plasticizer Gliserol Terhadap Karakteristik Edible Film dari Pati Kentang (Solanum tuberosum L.)," Skripsi, pp. 1-67, 2017.

[19] D. Maisa Putra and A. Alfauzain, "Design Of Tracer Using Microsoft Access Unit In Medical Record Primary Health In Padang," Int. J. Eng. Sci. Inf. Technol., vol. 1, no. 3, 2021, doi: 10.52088/ijesty.v1i3.90.

[20] F. W. Mahatmanti, W. Sugiyo, and W. Sunarto, "Sintesis Kitosan Dan Pemanfaatannya Sebagai Anti Mikrobia Ikan Segar," Sint. Kitosan Dan Pemanfaatannya Sebagai Anti Mikrobia Ikan Segar, vol. 8, no. 2, pp. 101-111, 2010, doi: 10.15294/sainteknol.v8i2.328.

[21] R. A. Rachmania, F. Nisma, and E. Mayangsari, "Ekstraksi Gelatin Dari Tulang Ikan Tenggiri Melalui Proses Hidrolisis Menggunakan Larutan Basa," Media Farm. J. Ilmu Farm., vol. 10, no. 2, pp. 18-28, 2013, doi: 10.12928/mf.v10i2.1167.

[22] D. Lantara, R. Kalla, and I. Asnawi, "Produksi Akrolein Dengan Proses Degradasi Menggunakan Gelombang Suara," J. Chem. Process Eng., vol. 4, no. 2, pp. 97-102, 2019, doi: 10.33536/jcpe.v4i2.469.

[23] B. A. B. Ii, T. Tipe, and P. Luka, "2 . 1 Pembalut Luka Pembalut luka biasanya dipakai untuk mempercepat berbagai tahap penyembuhan luka dan dapat menciptakan kondisi yang lebih baik untuk penyembuhan . Pembalut luka yang dipilih harus memiliki kriteria antara lain dapat mengatur kelembaban," pp. 17-29, 2017.

[24] S. Wahyuni et al., "Esterifikasi Gliserol Dan Asam Lemak Jenuh Sawit Dengan Katalis Mesa Esterification of Glycerol Andsaturatedfatty Acids of Palm Oil Withmesa As Catalyst," J. Teknol. Ind. Pertan., vol. 26, no. 3, pp. 333-342, 2016.

[25] C. A. Tanjung, "Pengaruh suhu dan waktu terhadap ekstraksi gelatin dari kulit ikan gabus," Tek. Kim. Univ. Muhammadiyah Palembang, 2020.

[26] N. Nuryati, J. D. Jaya, and N. Norhekmah, "Pembuatan Plastik Biodegradable Dari Pati Biji Nangka," J. Teknol. Agro-Industri, vol. 6, no. 1, p. 20, 2019, doi: 10.34128/jtai.v6i1.83.

[27] W. Syahputra, "Sintesa dan Karakterisasi Hibrid Kitosan-Limbah Kulit Pisang dengan Berpenguat Lignin Sebagai Pembalut Luka Antibakterial A-189 A-190,” vol. 2, no. 1, pp. 189-194, 2018. 